WORKING PAPER NO. 20

December 1997

\title{
Repong Damar: \\ Kajian tentang Pengambilan Keputusan dalam Pengelolaan Lahan Hutan di Pesisir Krui, Lampung Barat
}

\author{
Zulkifli Lubis
}

\begin{abstract}
Ringkasan
Proses pengelolaan hutan di pesisir Krui, Lampung Barat, biasanya terdiri dari tiga tahapan, yaitu dimulai dari ladang, kebun dan berakhir dengan repong damar. Kajian ini menunjukkan peranan faktor-faktor ekonomi, ekologi, dan sosial budaya dalam mempengaruhi proses pengambilan keputusan para petani Krui dalam konteks pengelolaan lahan hutan. Kesinambungan pengelolaan hutan secara lestari dengan sistem repong damar (damar agroforest) tergantung kepada respon petani Krui terhadap dinamika hubungan antara empat faktor tersebut dalam memenuhi kebutuhan hidup mereka.
\end{abstract}

CENTER FOR INTERNATIONAL FORESTRY RESEARCH

office address: Jalan CIFOR, Situ Gede, Sindangbarang, Bogor 16680, Indonesia

mailing address: P.O. Box 6596 JKPWB, Jakarta 10065, Indonesia

tel.: +62 (251) 622622 fax: +62 (251) 622100

email: cifor@cgnet.com

$W W W:$ http://www.cgiar.org/cifor 


\section{The CGIAR System}

The Consultative Group on International Agricultural Research (CGIAR) is an informal association of 41 public and private sector donors that supports a network of sixteen international agricultural research institutes, CIFOR being the newest of these. The Group was established in 1971. The CGIAR Centers are part of a global agricultural research system which endeavour to apply international scientific capacity to solution of the problems of the world's disadvantaged people.

\section{CIFOR}

CIFOR was established under the CGIAR system in response to global concerns about the social, environmental and economic consequences of loss and degradation of forests. It operates through a series of highly decentralised partnerships with key institutions and/or individuals throughout the developing and industrialised worlds. The nature and duration of these partnerships are determined by the specific research problems being addressed. This research agenda is under constant review and is subject to change as the partners recognise new opportunities and problems. 


\section{Daftar Isi}

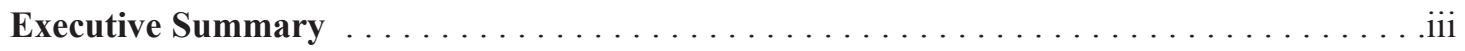

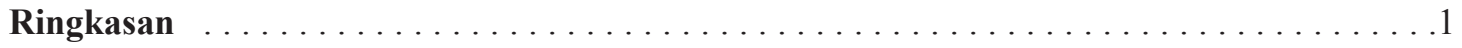

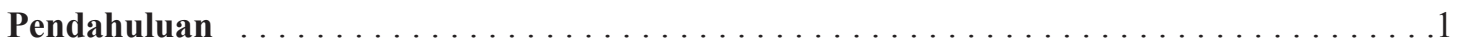

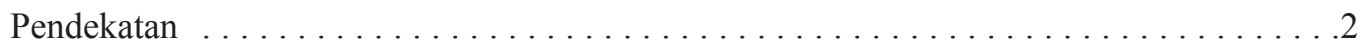

Karakteristik Lokasi Penelitian $\ldots \ldots \ldots \ldots \ldots \ldots \ldots \ldots \ldots \ldots \ldots \ldots \ldots$

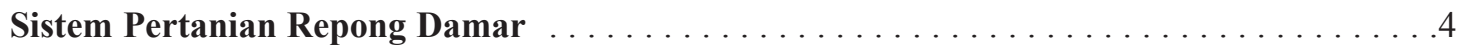

Mengenal Repong Damar $\ldots \ldots \ldots \ldots \ldots \ldots \ldots \ldots \ldots \ldots \ldots \ldots \ldots \ldots$

Proses Pengelolaan Lahan Hutan . . . . . . . . . . . . . . . . . . . . 6

Repong Damar dalam Perekonomian Rumah Tangga . . . . . . . . . . . . . . . . . . . 99

Pengaruh-pengaruh yang Mendasari Pengambilan Keputusan $\ldots \ldots \ldots \ldots \ldots \ldots \ldots$

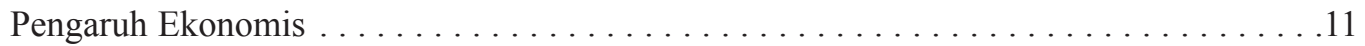

Pengaruh Ekologis . . . . . . . . . . . . . . . . . . . . . . . . . . . 12

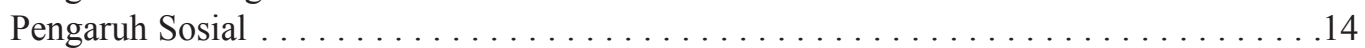

Pengaruh Kultural $\ldots \ldots \ldots \ldots \ldots \ldots \ldots \ldots \ldots \ldots \ldots \ldots \ldots \ldots \ldots \ldots$

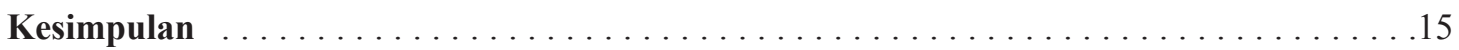

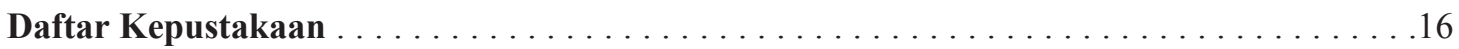




\section{Executive Summary}

\section{Damar (Shorea javanica): Study on Decision-Making of Forest Land Management of Pesisir Krui, West Lampung}

\section{Introduction}

This paper is a summary of case study research conducted in collaboration between Pusat Pengkajian dan Pengembangan Antropologi Ekologi, University of Indonesia (P3AE UI) and CIFOR. This research is part of my Master's thesis at the Anthropology Post-Graduate Program University of Indonesia. Fieldwork was conducted during August-November 1995 in Penengahan (Pesisir Tengah) and Malaya (Pesisir Utara), West Lampung. The fieldwork was conducted to answer the question "Why do Krui villagers maintain or conserve damar agroforest?". The research specifically examined influences for maintaining or converting the damar agroforest.

\section{Approach}

The study focused on household decision-making as an entry point to identify influences underlying changes in land and forest management in Pesisir Krui. Case studies of twelve household in two villages were used. Data were collected using interviews and biweekly monitoring of harvesting and management in the damar agroforest.

\section{Three production phases in agroforest management}

A sequence of three production phases are used by Krui farmers in management of the agroforest, darak (dry rice field), kebun (cash crop plantation) and repong (damar agroforest). After clearing forest land, farmers cultivate rice and annual crops in the darak. The aim of this phase is mainly to fulfill their subsistence needs. This phase occurs for a short period of time, one to two years. The second phase is kebun, where they maintain tanaman muda or perennials with quick yields for commercial purposes. They cultivate coffee, pepper or cloves for 10 to 15 years. Krui farmers call this phase batin kejutan, implying they will get the opportunity of having a large cash income from these crops. The third, is damar agroforest phase which they call a repong. They grow many kinds of tanaman tua or perennials requiring longer time periods before yielding benefits, such as damar, duku, durian, petai, jengkol etc. The damar agroforest becomes economically productive approximately in the 20th year after opening the forest land.

Krui farmers are not swidden farmers in the classic sence. Once the decision to open the forest land has been made, they already have expectations of benefits from long-term agroforest management. They do not leave the field to fallow and return to forest. Instead, the fields are managed continuously. In the first and second year of cultivation dry rice field production and horticulture help them to meet food needs during the time when they begin to plant in the perennials. The production harvested from coffee, pepper or cloves usually will be used for specific occasions such as to build a new house, pay mortgage for damar agroforest or rice field, for capital in their business, to pay for their children's education and to make pilgrimage to Mecca. Production from the damar agroforest, especially damar resin and fruits are spent for daily household needs.

\section{Influences on the sustainability of the damar agroforest}

Four types of influences, economic, ecology, social and cultural affect how Krui farmers sustain the damar agroforest. Economic influences are related to subsistence and monetary benefits from the three cultivation phases. Ecological influences are the specific ecological benefits that support the Krui farmers' livelihoods, for example fertile soils. Social influences are befenits derived from maintaining good social relations with family, neighbors and village leaders. Cultural influences are the sanctions and rewards associated with knowledge, belief, philosophy of life and world view that encourage farmers to manage forest land using damar agroforest system. 


\section{Economic influences}

The three phases of damar agroforest provide benefits to farmers continuously by fulfiling family needs for food and cash. Dry rice field management provides a food supply for farmers while they wait for their perennial crops to yield. Selling agroforest products, such as damar resin provides a stedy flow of cash, while fruits provide both cash and subsistence income.

\section{Ecological influences}

Krui farmers are familiar with the ecological characteristics of the forest land and seek to derive benefits there from. They evaluate soil quality and micro climate before they open the forest land. Soil is assessed by observing the color of the soil and type of vegetation. This knowledge is used by the farmers to choose which plants varieties to cultivate. In choosing plant combinations, the farmers avoid plants with parasitic relations and instead seek combinations with symbiotic relations wherever possible.

\section{Social and Cultural Influences}

Forest opening and management usually is not done individually, Krui farmers work with their immediate families and other relatives. They have institutions of ketulungan and bebelinan (mutual assistance) where they involve other people to help manage the agroforest. Management involves families from multiple generation (father and son) to open and manage the agroforest land. As a result the knowledge necessary to create agroforests is maintained. Another social aspect is that the eldest son of the family usually owns a larger land area of agroforest, because they have acquired this through their inheritance, while the youngest son has to clear forest to make his own agroforest. The extent of the agroforest not only indicates the farmers' social status, but is also considered as important trusteeship for the next generation.

\section{Conclusion}

The study reveals that there are several influences that affect how Krui farmers manage their land, namely economic, ecological, social and cultural influences. The cumulative effect of those influences is to strongly encourage farmers to maintain the damar agroforest as the most advantageous form of land use. Each management phase (darak, plantation and damar) contributes to each other so that the risk of failure in agricultural activities will be minimized. The continuity of the repong system will be determined by the role and interaction of four influences in the process of decision making made by the farmers. 


\title{
Repong Damar: Kajian tentang Pengambilan Keputusan dalam Pengelolaan Lahan Hutan di Pesisir Krui, Lampung Barat
}

\author{
Zulkifli Lubis $^{1}$
}

\section{Ringkasan}

Proses pengelolaan hutan di pesisir Krui, Lampung Barat, biasanya terdiri dari tiga tahapan, yaitu dimulai dari ladang, kebun dan berakhir dengan repong damar. Kajian ini menunjukkan peranan faktor-faktor ekonomi, ekologi, dan sosial budaya dalam mempengaruhi proses pengambilan keputusan para petani Krui dalam konteks pengelolaan lahan hutan. Kesinambungan pengelolaan hutan secara lestari dengan sistem repong damar (damar agroforest) tergantung kepada respon petani Krui terhadap dinamika hubungan antara empat faktor tersebut dalam memenuhi kebutuhan hidup mereka.

\section{PENDAHULUAN}

Kerusakan lingkungan hidup adalah satu dari tiga krisis global ${ }^{2}$ yang dihadapi umat manusia dewasa ini, dan penciutan kawasan hutan merupakan salah satu wujudnya. ${ }^{3}$ Proses deforestasi dan kerusakan lingkungan itu membawa dampak negatif pada keseimbangan ekologi dan iklim bumi, dan juga mengaki- batkan komunitas lokal yang berdiam di dalam dan di sekitar hutan harus menempati posisi marjinal. ${ }^{4}$

Namun satu fenomena menarik yang muncul menjelang akhir abad ini adalah mulai berkembangnya kesadaran, refleksi kritis dan peralihan paradigma di kalangan ilmuwan dan pembuat kebijakan dalam merespon dan memahami arti penting keberadaan hutan. Kini kelestarian hutan bukan hanya dilihat seba-

Zulkifli Lubis adalah pengajar tetap pada jurusan Antropologi Fakultas Ilmu Sosial dan Ilmu Politik, Universitas Sumatera Utara (USU), Medan. Menyelesaikan studi (S2) pada Program Studi Antropologi, Program Pascasarjana Universitas Indonesia tahun 1996. Makalah ini merupakan sebagian dari laporan penelitian lapangan yang diselenggarakan atas fasilitasi dari Program Penelitian dan Pengembangan Antropologi Ekologi Universitas Indonesia (P3AE-UI) bekerja sama dengan CIFOR.

2 Kemiskinan, kegagalan lingkungan hidup dan tindak kekerasan sosial adalah tiga jenis krisis global yang menurut Korten (1993) mengancam umat manusia selama dekade 1980-an. Lihat David C. Korten, Menuju Abad ke-21: Tindakan Sukarela dan Agenda Global; penerbit Yayasan Obor Indonesia; Jakarta, 1993.

3 Dalam kurun waktu 1980-1986 terjadi penciutan kawasan hutan Indonesia sebanyak 5,2 juta hektar atau rata-rata 853.000 ha pertahun (Salim 1992:10). John C. Ryan (1993:15) menyebutkan bahwa hamir 50.000 jenis spesies hewan tak bertulang punah setiap tahun (rtarata 140 jenis perhari) yang terjadi karena habitatnya di hutan tropika mengalami kerusakan. Sementara itu Harian Republika (18 Mei 1995) memberitakan bahwa sedikitnya 44 \% dari total hutan Indonesia seluas 143 juta hektar mengalami perubahan sebagai dampak pesatnya pembangunan serta pertumbuhan penduduk. Perubahan habitat tersebut mengakibatkan sejumlah spesies terancam punah, di antaranya 126 jenis burung, 62 jenis mamalia dan 21 jenis reptil.

4 Penduduk lokal sering dinilai tidak efisien dalam mengelola hutan dan dituding sebagai aktor perusak hutan sehingga potensi dan kemampuan mereka yang sesungguhnya dalam memelihara dan melestarikan hutan seringkali terabaikan. Kebijakan yang berlaku juga tidak jarang bersifat membatasi akses mereka dalam pemanfaatan sumberdaya yang ada di sekelilingnya. Lebih jauh lihat Zerner (1990), Tjitradjaja (1992) dan Moniaga (1993). 
gai kondisi yang niscaya bagi keselamatan bumi manusia, akan tetapi juga sudah dikaitkan dengan soal hak hidup dan harkat kemanusiaan penduduk yang teritori dan tradisi sosio-ekonominya bergantung kepada keberadaan hutan. Beberapa tahun terakhir ini telah berkembang pemikiran tentang pentingnya memperkuat posisi komunitas lokal dalam pengelolaan dan pemanfaatan sumberdaya (Korten 1987), yang dalam konteks kehutanan kemudian diwujudkan lewat programprogram perhutanan sosial dan hutan kemasyarakatan (Vergara 1983; Rao 1984; Cernea 1988; Poffenberger 1990).

Berbagai publikasi yang ada (lihat misalnya Bulmer 1982; Rathakette 1984; Mary \& Michon 1987; Dove 1993; Atmaja 1993; Michon \& de Foresta 1994; Tjitradjaja dkk 1994; LATIN 1995) bahkan telah menunjukkan kesalahan-kesalahan asumsi masa lalu yang memandang sepele kemampuan penduduk lokal dalam mengelola sumber daya hutan secara baik dan berkelanjutan. Kajian mereka mengungkapkan bahwa komunitas lokal sebenarnya memiliki dan mampu mengembangkan institusi-institusi yang kondusif bagi pengelolaan sumber daya berkelanjutan: ajeg secara ekologis, ekonomis maupun sosial budaya.

Pengelolaan repong damar di daerah pesisir Krui Lampung Barat, Propinsi Lampung, adalah satu contoh pengelolaan lahan hutan yang telah banyak dan masih terus mendapat perhatian para peneliti. Kajian-kajian yang ada telah mengulas beragam segi mengenai sistem pertanian penduduk asli Krui, antara lain aspek ekologis dan botanis (Michon dan de Foresta, Dupain, Levang, dll); aspek sosial ekonomi (Mary \& Michon 1987); aspek pengembangan institusi (Tjiradjaja dkk 1994; Juhadi 1996); aspek tataniaga resin damar (LATIN 1994; Eridwiantari 1995); konsepsi penduduk mengenai ruang dan pemanfaatan sumberdaya (Nadapdap 1995) dan juga kajian tentang struktur keluarga dan rumah tangga petani damar (Fikarwin 1995).

Tulisan ini akan mengulas segi lain dari pengelolaan repong damar di Krui, yang sejauh ini belum banyak mendapat perhatian peneliti, yaitu aspek pengambilan keputusan dalam konteks pengelolaan lahan hutan. Fokus kajian adalah mengungkapkan pengaruh-pengaruh yang mendasari keputusan petani damar Krui untuk mempertahankan atau mengkonversi repong damar. Dengan pengungkapan pengaruhpengaruh tersebut akan terjawab dua pertanyaan pokok, yaitu (1) mengapa penduduk di daerah pesisir Krui memilih dan tetap mempertahankan repong damar sebagai bentuk pemanfaatan lahan hutan; dan (2) mengapa mereka mengkonversi damar ke cengkeh pada era 1970 -an.
Temuan lapangan mengenai pengaruh-pengaruh yang mendasari keputusan petani dalam mengelola lahan hutan menjadi ladang, kebun, repong damar atau bentuk pengelolan lain penting untuk memahami dinamika pengelolaan lahan hutan. Informasi itu juga penting untuk memperkirakan kecenderungan perubahan yang mungkin terjadi di masa depan sebagai respon petani terhadap rangsangan-rangsangan yang datang dari dalam maupun dari luar komunitas pengguna hutan.

\section{Pendekatan}

Kajian tentang proses pengambilan keputusan, termasuk dalam konteks pertanian, biasanya berorientasi pada analisa pelaku (actor-oriented analysis) dengan menekankan keberagaman perilaku di dalam suatu konteks institusi, kebiasaan dan kondisi-kondisi lokal (Barlett 1980:8). Kajian demikian bisa dikategorikan sebagai pendekatan prosesual (Orlove 1980:246), yang dapat dibedakan atas dua tipe, yaitu (1) model kognitif atau naturalistik, (2) model mikroekonomik. Model kognitif berusaha melukiskan proses-proses psikologis yang aktual dalam pengambilan keputusan dengan menempatkan sejumlah alternatif dan prosedur untuk memilihnya; sedangkan model mikroekonomik menganilisis pengambilan keputusan dengan menggunakan perangkat analisis mikro ekonomik.

Dalam kajian ini pendekatan yang bernuansa kognitif digunakan untuk menjelaskan bagaimana petani damar mengkonsepsikan pilihan dan harapan mereka berkaitan dengan strategi pertaniannya, dan bagaimana mereka memanfaatkan konsepsi atau pengetahuan itu dalam menentukan pilihan dan memanfaatkan peluang dalam pengelolaan lahan hutan. Argumentasi mengenai hal itu diperkuat dengan menampilkan data-data empirik mengenai aspek ekonomi dari kasus-kasus pengelolaan lahan yang dilakukan petani Krui.

Unit analisis yang digunakan adalah rumah tangga. Hal ini didasarkan pada asumsi bahwa keputusankeputusan yang diambil dalam konteks pengelolaan lahan hutan, terutama dalam rangka pemenuhan kebutuhan ekonomi, akan senantiasa disesuaikan dengan dan dipengaruhi oleh kebutuhan para anggota sebuah rumah tangga. ${ }^{5}$ Data dikumpulkan melalui pengamatan, wawancara, survey partisipatoris dan pemanfaatan sumber-sumber sekunder. Kerja lapangan dilakukan selama empat bulan (akhir Juli-Nopember 1995).

Wawancara dilakukan terhadap sejumlah informan dan kepala rumah tangga di dua desa lokasi penelitian. Kemudian 12 rumah tangga di antaranya dipilih secara

\footnotetext{
5 Signifikansi penggunaan rumah tangga sebagai unit analisis antara lain dikemukakan oleh Barlett (1980), Mc Netting (1983), dan Lila E. Engberg (1988).
} 
purposive (berdasarkan perbedaan tingkat sosial ekonomi) untuk pendalaman kasus pengambilan keputusan dalam pengelolaan hutan dan strategi mata pencaharian hidup mereka pada umumnya. Pengumpulan data untuk kasus rumah tangga sampel dilakukan setiap dua minggu selama dua bulan. Data yang diperoleh dalam tempo sesingkat itu sebenarnya belum memadai untuk kepentingan analisis, karena fakta di lapangan menunjukkan bahwa variabel musim dan kalender aktivitas pertanian penduduk setempat sangat berpengaruh terhadap dinamika kehidupan ekonomi rumah tangga.

\section{Karakteristik Lokasi Penelitian}

Penelitian lapangan dilakukan di Desa Penengahan (Kec. Pesisir Tengah Krui) dan Desa Malaya (Kec. Pesisir Utara), Kabupaten Lampung Barat. Keduanya memiliki segi-segi yang berbeda dalam latar belakang sejarah, pola pemanfaatan lahan dan strategi ekspansi meskipun corak ekosistemnya relatif sama. Dalam konteks pengelolaan lahan hutan Desa Penengahan adalah representasi komunitas yang konsisten mempertahankan sistem wanatani damar, sementara Desa Malaya mewakili komunitas yang memiliki sekuen sejarah konversi damar ke cengkeh pada era 1970-an. Kedua desa terpaut jarak sekitar $40 \mathrm{~km}$. Penengahan terletak sekitar $5 \mathrm{~km}$ dari Pasar Krui (pusat perdagangan di daerah pesisir Krui) dan $1 \mathrm{~km}$ di luar jalan lintas provinsi; sedangkan Malaya berjarak sekitar 45 $\mathrm{km}$ dari Pasar Krui dan berada di lintasan jalan provinsi (Jalur Lintas Barat).

Sebagian besar penduduk pesisir Krui, khususnya di desa Penengahan dan Malaya, hidup dari pertanian. Mereka mengerjakan sawah, ladang, kebun dan repong damar. Penduduk asli yang mendiami kawasan ini adalah Orang Krui yang merupakan bagian dari etnik Lampung. Mereka berdiam di daerah yang ekosistem- nya hampir sama, yaitu bagian kawasan hutan hujan tropik, dekat dengan pantai di sebelah barat dan berbatasan dengan hutan kawasan Taman Nasional Bukit Barisan Selatan (TNBBS) disebelah utara dan timur laut.

Luas wilayah Desa Penengahan sekitar $15.30 \mathrm{~km}^{2}$ membentang di sepanjang Sungai (Way) Laay, Way Simpang Kiri dan Way Simpang Kanan hingga ke batas hutan kawasan TNBBS. Sebagian besar wilayahnya merupakan perbukitan terjal yang di bawahnya mengalir banyak anak sungai. Penduduk berjumlah 2.266 jiwa, terdiri dari $348 \mathrm{KK}$. Kepadatan penduduknya 148 orang $/ \mathrm{km}^{2}$. Lahan hutan yang masih bisa dibuka tidak ada lagi, sehingga hampir $2 / 3$ dari jumlah KK yang ada (sekitar 216 KK) membuka lahan pertanian di tempat lain yang tersebar di wilayah pesisir Krui.

Penduduk Penengahan tergolong homogen dari segi etnis dan agama. Mereka terdiri dari orang asli Krui yang seluruhnya beragama Islam. Berdasarkan silsilah keturunan, orang Penengahan membedakan dirinya atas empat keluarga luas (klen patrilineal) yang disebut kampung, yaitu Kampung Batin, Berak, Sukajama dan Kuta Besi. Pada masa kolonial, mereka menjadi bagian dari kesatuan administratif Marga Laay. Lahan pertanian yang ada di desa Penengahan sebagian besar dikuasai oleh warga Kampung Batin dan Kampung Berak, yang juga mayoritas dalam komposisi penduduk.

Desa Malaya dua kali lebih luas dari Penengahan, yaitu $33,41 \mathrm{~km}^{2}$. Dengan penduduk yang hanya berjumlah 1.378 jiwa atau $256 \mathrm{KK}$, maka ruang hidup bagi penduduk Malaya sebenarnya jauh lebih luas dari orang Penengahan (kepadatan 41 orang $/ \mathrm{km}^{2}$ ). Hingga awal 1980-an areal hutan primer masih cukup luas di wilayah desa Malaya, yang sebelumnya tidak digarap karena masih berstatus hutan larangan marga (Marga Malaya). Tapi sejak 1980 areal hutan tersebut mulai

Tabel 1. Karakteristik Umum Desa Penelitian

\begin{tabular}{|l|l|l|l|}
\hline No. & Karakteristik & Desa Penengahan & Desa Malaya \\
\hline 1 & Luas desa & $15.30 \mathrm{~km}^{2}$ & $3.41 \mathrm{~km}^{2}$ \\
2 & Jumlah penduduk & 2.266 jiwa & 1.378 jiwa \\
3 & Jenis kelamin & & \\
& Laki-laki & 1.182 jiwa & 736 jiwa \\
& Perempuan & 1.084 jiwa & 642 jiwa \\
4 & Jumlah KK & $348 \mathrm{KK}$ & $256 \mathrm{KK}$ \\
5 & Usia produktif & 1.393 jiwa & 824 jiwa \\
6 & Asal etnis & Krui, Jawa & Krui,Jawa,Sunda,Batak \\
7 & Klen (kampung) & Berak,Sukajama, Kutabesi, Batin & Batin,Penyandingan, Jejerlawok, Masagus \\
8 & Modus pendidikan & Sekolah Dasar & Sekolah Dasar \\
9 & Agama & Islam & Islam \\
10 & Mata pencaharian pokok & bertani & bertani \\
\hline
\end{tabular}


digarap oleh migran Jawa dan pendatang dari pesisir tengah Krui (termasuk penduduk asal desa Penengahan), sehingga penduduk asli Malaya hanya bisa memanfaatkan hutan-hutan sekunder di dalam wilayah yang secara tradisional menjadi hak mereka dan sejak lama telah dimiliki secara privat.

Penduduk Malaya terdiri dari penduduk asli (Orang Krui) dan sejumlah kecil migran Jawa, Sunda dan Batak. Semuanya beragama Islam. Penduduk asli mendiami pinggiran pantai dekat muara Way Malaya; sedangkan penduduk pendatang kebanyakan berdiam di dukuh Batu Bulan dan Nusa Damai (Kakabu), kirakira 5-7 km masuk ke pedalaman (berada di dalam kawasan hutan larangan marga dan berbatasan dengan hutan kawasan TNBBS). Orang Malaya asli juga terdiri atas 4 klen patrilineal, yaitu Kampung Batin, Penyandingan, Jejerlawok dan Masagus.

\section{SISTEM PERTANIAN REPONG DAMAR}

Secara umum sistem pertanian di daerah Krui merupakan gabungan yang saling mendukung antara pertanian lahan basah (khususnya sawah) dengan lahan kering (sistem wanatani damar). Sampai batas-batas tertentu keberadaan sawah punya andil terhadap keberlanjutan wanatani damar, karena alokasi waktu yang dicurahkan untuk mengelola sawah akan mengurangi tekanan untuk mengeksploitasi hasil repong damar. Data-data empirik menunjukkan bahwa kegiatankegiatan produktif di repong damar berkurang selama musim panen padi. ${ }^{6}$

Lahan yang bisa dijadikan areal persawahan sangat sempit, dan hanya sebagian kecil penduduk yang memiliki sawah. Sekalipun demikian, bersawah tetap menjadi lakon kehidupan ekonomi yang penting bagi penduduk Penengahan dan Malaya untuk memasok kebutuhan pangan. Petak-petak sawah hanya terdapat di dataran sempit di pinggir pantai atau di selokan bukit, dan tidak berpeluang untuk diperluas lagi. Rata-rata hasil sawah sekali panen hanya mampu menyumbang pasokan beras sebanyak 39,3 $\mathrm{kg} /$ orang di Penengahan dan 75,3 $\mathrm{kg} /$ orang di Malaya.
Sebagian penduduk mengatasi kelangkaan pangan dengan membuka ladang dan menanam padi gogo. Kegiatan itu berlangsung dengan cara membuka hutan alam, sebagian masih berupa hutan primer, namun beberapa dekade terakhir ini lahan yang dibuka lebih dominan berupa hutan sekunder. Tapi harus dipahami bahwa menanam padi ladang bukan tujuan utama dalam proses pembukaan lahan sebagaimana disimpulkan oleh Mary \& Michon (1987:42). Orang Krui menanam padi ladang sebagai fase awal dari proses pembangunan repong damar. Hasilnya lebih ditujukan untuk mencukupi pasokan pangan selama mengurus tanaman produktif pada fase kedua (fase kebun). Argumentasi untuk ini akan diuraikan pada bagian lain di bawah.

\section{Mengenal Repong Damar}

Orang Krui menyebut hutan alam dengan istilah pulan dan wanatani damar dengan istilah repong. Struktur vertikal dan ekosistem pulan dan repong tidak jauh berbeda. Keduanya ditandai oleh tingginya diversitas dan heterogenitas biota alam yang menjadi komponennya. Kombinasi mosaik pulan dan repong yang menghampar hijau kini telah menutupi gugusan perbukitan di sepanjang pantai barat provinsi Lampung hingga ke batas Taman Nasional Bukit Barisan Selatan (TNBBS) di sebelah utara dan timur laut. Luas hamparan hijau yang dominan berupa repong damar itu ditaksir telah melampaui 10.000 ha dan menghasilkan resin damar sekitar 10.000 ton pada tahun 1994 (Michon \& de Foresta, 1994:6).

Tabel 2. Produksi padi di Desa Penengahan dan Malaya

\begin{tabular}{|l|l|l|l|}
\hline No. & Karakteristik & $\begin{array}{c}\text { Desa } \\
\text { Penengahan }\end{array}$ & \multicolumn{1}{|c|}{$\begin{array}{c}\text { Desa } \\
\text { Malaya }\end{array}$} \\
\hline 1 & Jumlah atar $^{7}$ & 9 atar & 25 atar \\
2 & Luas sawah & $31,2 \mathrm{ha}$ & $42,6 \mathrm{ha}$ \\
3 & Jumlah keluarga pengelola & $99 \mathrm{KK}$ & $103 \mathrm{KK}$ \\
4 & Rata-rata hasil gabah sekali panen & $140 \mathrm{ton}$ & $163 \mathrm{ton}$ \\
5 & Konversi ke beras & $89,1 \mathrm{ton}$ & $103,7 \mathrm{ton}$ \\
6 & Kontribusi rata-rata per jumlah & $39,3 \mathrm{~kg} /$ orang & $75,3 \mathrm{~kg} /$ orang \\
& penduduk & 2x setahun & $1-2 \mathrm{x}$ setahun \\
\hline
\end{tabular}

Sumber: Wawancara dan Survei Partisipatoris

\footnotetext{
FA (38 tahun), seorang pedagang damar di Penengahan menyebutkan bahwa pada hari-hari biasa ia bisa menampung 0,5-1 ton getah damar perhari, tapi menurun menjadi $<500 \mathrm{~kg}$ pada musim panen padi.

7 Atar adalah terminologi lokal untuk menyebutkan suatu hamparan lahan yang terletak di satu lokasi tertentu dan dibuka pada kurun waktu yang sama. Setiap atar mempunyai nama khusus yang menjadi tanda pengenal bagi penduduk, biasanya menggunakan nama tumbuhan, bukit, sungai, atau gejala alam lainnya.
} 
Tabel 3. Gambaran Produksi Lahan Darak (kering) di Penengahan dan Malaya

\begin{tabular}{|c|c|c|c|}
\hline No. & Karakteristik & Penengahan & Malaya \\
\hline 1 & Lahan darak & 53 atar & 46 atar \\
\hline 2 & $\begin{array}{l}\text { Repong damar } \\
\text { a. Produksi per bulan } \\
\text { b. Harga jual } \\
\text { c. pendapatan } \\
\text { d. Kontribusi rerata/KK/bln }\end{array}$ & $\begin{array}{l}876 \text { bidang } \\
40-50 \text { ton } \\
\text { Rp. } 1.250,00 / \mathrm{kg} \\
48-60 \text { juta } \\
144-180 \text { ribu }\end{array}$ & $\begin{array}{l}339 \text { bidang } \\
14-20 \text { ton } \\
\text { Rp. } 1.200,00 / \mathrm{kg} \\
16,8-24 \text { juta } \\
66-94 \text { ribu }\end{array}$ \\
\hline 3 & $\begin{array}{l}\text { Kebun lada } \\
\text { a. Produksi / tahun } \\
\text { b. Harga jual } \\
\text { c. Pendapatan } \\
\text { d. Kontribusi rerata/KK }\end{array}$ & $(*)(* *)$ & $\begin{array}{l}143 \text { bidang } \\
78,5 \text { ton } \\
\text { Rp. } 3500 / \mathrm{kg} \\
\text { Rp. } 27,5 \text { juta } \\
\text { Rp. } 107 \text { ribu }\end{array}$ \\
\hline 4 & $\begin{array}{l}\text { Kebun kopi } \\
\text { a. produksi /tahun } \\
\text { b. Harga jual } \\
\text { c. Pendapatan } \\
\text { d. Kontribusi rerata/KK }\end{array}$ & $\begin{array}{l}215 \text { bidang }(* *) \\
{[215 \text { ton] }} \\
\text { Rp. } 3.500,00 / \mathrm{kg} \\
\text { Rp. } 75,2 \text { juta } \\
\text { Rp. } 216 \text { ribu }\end{array}$ & $\begin{array}{l}160 \text { bidang } \\
91 \text { ton } \\
\text { Rp. } 3.500,00 / \mathrm{kg} \\
\text { Rp. } 31,8 \text { juta } \\
\text { Rp. } 124 \text { ribu }\end{array}$ \\
\hline
\end{tabular}

Sumber: Survei Partisipatoris dan Wawancara

Keterangan:

[*] jumlah tidak diketahui, biasanya ditanam bersamaan di kebun kopi

[ ] angka taksiran dengan asumsi 1 bidang menghasilkan 1 ton/panen [**] lokasi lahan tersebar di empat kecamatan

Dari segi teknis budidaya, tahap-tahap penanaman tanaman produktif (mulai dari tanaman subsisten sampai tanaman tua) berikut perawatannya, disengaja atau tidak oleh sang petani, ternyata berlangsung dalam kondisi ekologis yang sesuai dan saling mendukung satu sama lain. Sehingga prosesproses produksi yang terkait dalam seluruh tahapan pengembangan repong bisa membuahkan efisiensi penggunaan faktor-faktor produksi. Pada gilirannya, kegiatan produktif yang berlangsung secara bertahap itu akan memberikan kontribusi ekonomi bagi petani secara terus-menerus dalam jangka panjang. Resin damar yang dipanen secara berkala memberi pendapatan tunai secara rutin untuk nafkah keluarga. Dari repong juga bisa dipetik hasil tanaman lain seperti disebutkan di atas, plus kayu bakar, bahan bangunan dan juga beragam jenis tumbuhan obat.

Di desa Penengahan terda-

Kehidupan penduduk pesisir Krui banyak bergantung pada keberadaan repong damar ini. Repong dalam terminologi Krui adalah sebidang lahan kering yang ditumbuhi beraneka-ragam jenis tanaman produktif, umumnya tanaman tua (perennial crops), seperti damar, duku, durian, petai, jengkol, tangkil, manggis, kandis dan beragam jenis kayu yang bernilai ekonomis serta beragam jenis tumbuhan liar yang dibiarkan hidup. Disebut repong damar karena pohon damar merupakan tegakan yang dominan jumlahnya pada setiap bidang repong.

Repong damar adalah fase final dalam tahapan linier sistem pengelolaan lahan kering (darak) di daerah Krui, yaitu fase ketika lahan hutan (baik hutan primer maupun hutan sekunder) yang dibuka dan dibabat kandas akan mencapai format seperti hutan alam kembali setelah 20 tahun kemudian. Michon \& de Foresta (1994) menyebutkan bahwa secara ekologis fase perkembangan repong damar tersebut menyerupai tahapan suksesi hutan alam dengan segala keuntungan ekologisnya seperti perlindungan tanah, evolusi iklim mikro, dan lain sebagainya. pat 53 atar lahan kering yang seluruhnya terdiri dari 876 bidang $^{8}$ repong damar. Paling sedikit 4 atar diantaranya sudah berada dalam kawasan TNBBS. Sedangkan di Malaya ada 48 atar yang terbagi menjadi 658 bidang dan hanya 339 bidang diantaranya repong damar. Sisanya berupa kebun lada (143 bidang), kopi (160 bidang) dan bekas kebun cengkeh (15 bidang). Produksi resin damar dari Malaya berkisar antara 14-20 ton/bulan, dan desa Penengahan sekitar 40-50 ton/bulan. Dengan harga jual damar sekitar Rp 1.200,00/kg (keadaan bulan Nopember 1995), hasil tanaman damar memberikan kontribusi sebesar Rp. 16,8-24,0 juta untuk penduduk Malaya dan Rp. 48,0-60,0 juta bagi penduduk Penengahan. Jika diambil rata-rata, setiap keluarga mendapat kontribusi $\mathrm{Rp}$ 137.900-172.400 (desa Penengahan) dan Rp. 62.50093.750 (desa Malaya) dari hasil damar. Hasil lada dari Malaya diperkirakan sebanyak 78,5 ton pertahun. Sedangkan hasil kopi (yang kepemilikannya didominasi orang Jawa/Sunda) memberikan kontribusi sekitar 91 ton pertahun. Dengan tingkat harga lada dan kopi rata-rata $3.500,00 / \mathrm{kg}$ (musim panen 1995), produk

\footnotetext{
8 Bidang adalah istilah lokal yang mengacu kepada satu luasan lahan yang menjadi bagian dari suatu atar, yang dibuka dan kemudian dimiliki oleh sebuah keluarga. Luasnya tidak tertentu, biasanya berkisar 1 ha.
} 
lada menyumbang bagi perekonomian petani Malaya sebesar Rp 27,5 juta, sementara kopi memberi masukan sebesar Rp. 31,9 juta pertahun. Sayang sekali, data hasil kopi dan lada penduduk desa Penengahan tidak diperoleh secara memadai sehinggga upaya komparasi menjadi timpang. Hal ini terjadi karena kesulitan dalam pencarian data mengingat lokasi kebun kopi /lada mereka dan penjualan hasilnya yang menyebar di 3-4 kecamatan di kawasan Lampung Barat. ${ }^{9}$

\section{Proses Pengelolaan Lahan Hutan}

Orang Krui membedakan adanya dua tipe lahan hutan, yaitu pulan tuha (hutan primer) dan pulan ngura (hutan sekunder). Pulan tuha biasanya menjadi preferensi pertama dalam pemilihan lahan ketika seorang petani berniat membuka hutan untuk kegiatan pertanian. Ini disebabkan oleh adanya anggapan bahwa lahan demikian masih memiliki kesuburan yang cukup baik.

Secara umum pengambilan keputusan dalam memilih lahan hutan dipengaruhi oleh sejumlah faktor terkait antara lain (a) informasi tentang adanya lahan yang masih bisa digarap, (b) jarak relatif lokasi lahan dari pemukiman dan pasar, (c) status kepemilikan lahan, (d) penguasaan modal dan tenaga kerja, dan (e) keadaan tanah. Namun bagi penduduk desa Penengahan khususnya, tampaknya faktor jarak dan status lahan tidak menjadi pertimbangan penting. Hal ini berkaitan dengan fakta bahwa sejak 1960-an mereka sudah kehilangan peluang untuk membuka hutan alam di wilayah desanya, sehingga pilihan utama bagi mereka adalah melakukan ekspansi ke daerah lain.

Sebagai contoh, daerah Way Jambu (Kec. Pesisir Selatan), Pematang Lioh (Kec. Balik Bukit) dan Pugung (Kec. Pesisir Utara) yang merupakan titik-titik konsentrasi ekspansi migran asal Penengahan rata-rata berjarak $35 \mathrm{~km}$ dari desa Penengahan. Pada awal pembukaannya daerah-daerah tujuan ekspansi ini masih harus ditempuh dengan jalan kaki atau berlayar lewat laut. Para migran ini terus membuka lahan di sana meskipun mereka mengetahui bahwa sebagian lahan hutan yang ditebasnya sudah melampaui garis batas hutan kawasan TNBBS.

\section{Tiga fase produktif pengelolaan lahan hutan}

Tradisi pembukaan lahan hutan yang dilakukan orang Krui secara garis besar dapat dibedakan atas tiga fase produktif, yaitu fase (1) darak, (2) kebun, dan (3) repong. Ketiga fase itu berlangsung di ruang fisik yang sama tapi secara taksonomis berada pada ruang kognisi yang berbeda. Hal itu berkaitan dengan definisi, konsepsi dan harapan-harapan yang mereka lekatkan pada masing-masing fase pengelolaan tersebut. Perbedaan itu secara jelas dimanifestasikan dalam bentuk tindakan pengelolaan lahan.

Fase produktif pertama dimulai ketika petani sudah selesai mempersiapkan lahan siap tanam (pangrula/darak) yang lazimnya membutuhkan waktu sekitar 2-3 bulan. ${ }^{10}$ Fase darak (fase 1) ditandai oleh kegiatan pengelolaan tanaman subsistensi berupa padi ladang dan palawija. Kegiatan menanam padi ladang dan palawija dilakukan terutama untuk menyediakan pasokan pangan bagi petani selama pengelolaan lahan, khususnya selama tahap-tahap intensif perawatan tanaman kebun (fase 2). Padi dan palawija hanya ditanam 1-2 kali di lahan yang sama, setelah itu mereka mengalihkan kegiatannya pada perawatan tanaman komersial seperti kopi, lada, cengkeh dan lain sebagainya. Dengan demikian, fase darak (ladang) berfungsi sebagai penyangga bagi fase produktif berikutnya.

Fase produktif kedua, yaitu kebun, dimulai ketika tanaman komersial seperti lada, kopi, atau cengkeh, dll sudah mendominasi tegakan di lahan bekas ladang (fase 1), yaitu kira-kira mulai tahun ketiga sejak pembukaan lahan. Tujuan utama petani Krui membuka hutan adalah untuk berkebun, bukan berladang atau membuat repong damar. Fase kebun dikonsepsikan petani sebagai fase kaya kejutan (batin kejutan), karena pada masa inilah mereka mendapatkan peluang besar untuk meningkatkan kesejahteraan hidup dan memperbaiki posisi sosial ekonominya. Hasil kebun biasanya tidak digunakan untuk memenuhi kebutuhan subsistensi, tetapi lebih diarahkan kepada keperluankeperluan yang berciri monumental, misalnya membangun rumah, mengawinkan anak, membiayai pendidikan lanjutan anak, menebus dan/atau menerima harta gadaian, membeli repong damar atau sawah, modal berdagang, beli perabot rumah tangga, biaya naik haji, dll.

\footnotetext{
9 Angka-angka kuantitatif yang disajikan di sini diolah dari data-data yang diperoleh dari sumber primer (hasil survai partisipatoris dan wawancara dengan pedagang desa) kemudian dikomparasi dengan sumber sekunder.

10 Pekerjaan-pekerjaan yang dilakukan pada awal pembukaan hutan adalah: menebas (ngusi); menebang kayu (nuar); memotong dahan kayu (ngeredoh); membakar (nyuah); dan membersihkan sisa bakaran (merun). Pekerjaan ini dilakukan dengan menggunakan teknologi sederhana, dan pelaksanaannya sangat bergantung dengan musim kemarau. Proses penyiapan lahan ini merupakan bagian tugas tenaga kerja laki-laki.
} 
Tabel 4. Alternatif-alternatif jenis tanaman di darak

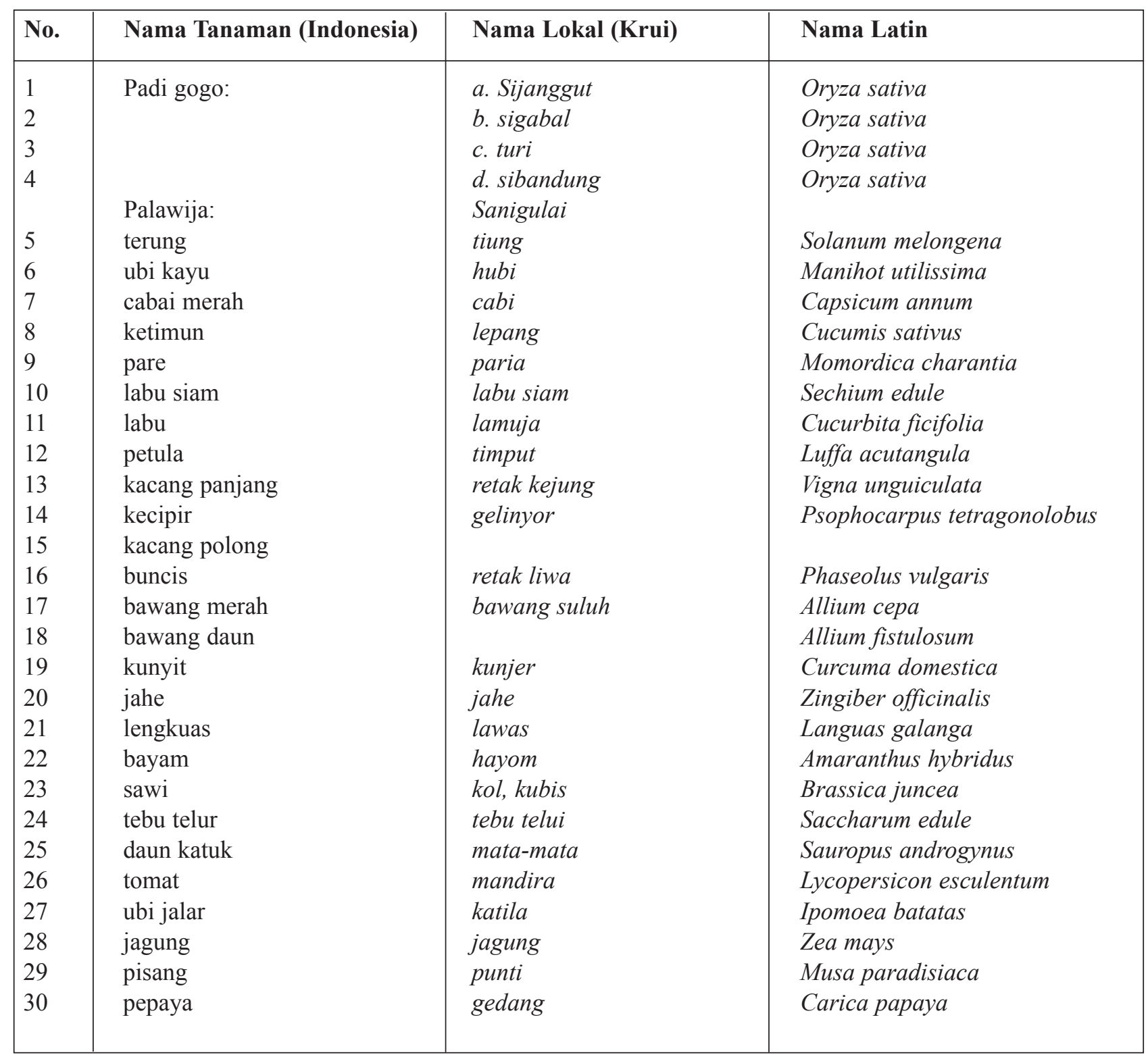

Sumber: Wawancara (1995)

Demikian penting peranan fase kebun ini di mata petani, suatu fase yang penuh ketidak-pastian (uncertainty) karena hasilnya, jika mencapai kategori yang disebut merawan, bisa menaikkan gengsi sebuah keluarga; tapi bila gagal bisa membuat mereka terpuruk tak mendapatkan peningkatan apa-apa. ${ }^{11}$ Fakta pentingnya kedudukan fase kebun di dalam sistem pertanian orang Krui ditandai oleh pelaksanaan sejumlah ritus dalam rangkaian pengelolaan tanaman hingga panen (yaitu ritus tetumbai pada saat mulai menanam, ritus ngejalang pada saat panen pertama, dan ritus ngumbai setelah panen); usaha optimalisasi pemanfaatan lahan; dan juga perawatan intensif.

Fase produktif ketiga. Orang Krui mulai menamakan lahan pertaniannya dengan repong apabila sudah terpenuhi unsur keragaman jenis tanaman keras

\footnotetext{
11 Petani Krui membuat tiga jenis klasifikasi kualitatif untuk mengukur tingkat keberhasilan mereka dalam fase kebun, yaitu (a) merawan, jika mendapatkan keberuntungan dan mampu mencapai tujuan-tujuan yang monumental, (b) cukoh-genok, jika hasil kebun hanya pas-pasan dan tidak memberi efek monumental, dan c) mesisil, jika usaha berkebun tidak memberikan hasil melainkan membawa kesialan bagi mereka.
} 
Tabel 5. Jenis-jenis Tanaman Produktif pada Fase Repong

\begin{tabular}{|l|l|l|l|}
\hline No. & Nama Tanaman (Indonesia) & Nama Lokal (Krui) & Nama Latin \\
\hline 1 & Damar mata kucing & damar kaca & Shorea javanica \\
2 & Duku & duku & Lansium domesticum \\
3 & Durian & durian & Durio zibethinus \\
4 & Petai & petar & parkia speciosa \\
5 & Jengkol & tangkil & Phitecelebium jiringa \\
6 & Melinjo & manggus & Gnetum gnemon \\
7 & Manggis & melasa & Artocarpus heterophyllus \\
8 & Nangka & pinang & Areca catechu \\
9 & Pinang & kayu manis & Cinnamomum burmanni \\
10 & Kayu manis & & \\
\hline
\end{tabular}

Sumber: Wawancara

(perennial crops) yang tumbuh di atasnya; misalnya damar, duku, durian, petai, jengkol, melinjo, nangka, dan lain sebagainya. Semua jenis tanaman itu secara berangsur sudah ditanam sejak fase kebun. Satu ciri penting yang membedakan fase kebun dengan repong terletak dalam soal perawatan tanaman. Tanaman di repong tidak memerlukan perawatan intensif seperti halnya tanaman kebun. Hal ini membawa implikasi pada residensi petani, yaitu berkurangnya kebutuhan untuk tetap tinggal di "hutan" seperti ketika mengurus ladang dan kebun, dan tibanya kesempatan bagi mereka untuk menetap kembali di desa. Saat yang demikian biasanya berlangsung antara tahun ke 10-15 (usai masa produktif kopi dan lada).

Salah satu penjelasan mengapa orang Krui tetap menanam damar berkaitan dengan perubahan residensi ini. Damar adalah unsur tanaman terpenting di dalam sistem repong, dan pengelolaan repong damar fungsional untuk menegaskan klaim hak atas lahan hutan yang sudah dibuka. Jika lahan bekas kebun ditinggalkan tanpa meneruskannya ke fase repong, maka lahan tersebut akan kembali menjadi hutan. Adat orang Krui menyatakan bahwa lahan yang dibiarkan menjadi rerahan/belukar dan pulan ngura/hutan sekunder boleh dibuka dan dikelola kembali oleh orang lain. Karena itu, membiarkan lahan bekas kebun menjadi belukar atau hutan kembali setelah ditinggalkan sama artinya dengan membiarkan lahan tersebut diambil alih orang lain. Tetapi jika lahan ditinggalkan setelah ditanami damar dan tanaman ikutan lainnya yang umurnya puluhan bahkan bisa ratusan tahun, maka lahan tersebut menurut aturan setempat dianggap tetap menjadi milik keluarga yang pertama sekali mengelolanya. ${ }^{12}$ Saya melihat posisi tanaman damar lebih kuat sebagai penegas klaim atas lahan dibandingkan tanaman repong lainnya karena dua alasan, (a) tradisi mengklaim lahan hutan yang ditumbuhi damar liar sudah berlangsung lama bahkan ketika orang Krui masih dalam fase mengekstraksi dan belum membudidayakan pohon damar, (b) damar merupakan tanaman yang bisa memberikan penghasilan rutin kepada petani.

Berbeda dengan tanaman kebun, orang Krui tidak menggolongkan damar sebagai tanaman yang bisa memberikan efek kejutan dan pencapaian-pencapaian yang bersifat monumental. Mereka menempatkan damar sebagai tanaman produktif unsur penunjang kebutuhan rutin rumah tangga. Dalam proses pengelolaan tanaman repong petani juga tidak membuat perhitungan matang tentang jumlah yang akan ditanam dan perkiraan hasilnya, juga tidak ada perlakuan istimewa semisal ritus-ritus yang berlaku untuk pengelolaan tanaman kebun. Semuanya berlangsung secara profan. Mereka mengaku "hanya menanam damar, bukan berkebun damar" dan menurut mereka menanam damar bukan karena pertimbangan harga, karena "tidak mungkin untuk memperkirakan harga damar 20 tahun yang akan datang".

Oleh sebab itu, repong damar adalah fase dimana petani menanam investasi yang hasilnya diharapkan

\footnotetext{
12 Kenyataan di lapangan mengindikasikan adanya variasi antara orang Penengahan dan orang Malaya dalam penegasan klaim hak atas lahan hutan yang pernah dibuka. Orang Malaya mengaku bisa mengklaim hak atas lahan hutan yang pernah dibuka tanpa keberadaan damar dan tanaman repong lainnya, sedangkan orang Penengahan menyatakan sangat rentan untuk membiarkan lahan tanpa tanaman repong. Hal ini tampaknya berkaitan dengan fakta bahwa orang Malaya tidak pernah melakukan ekspansi pembukaan lahan ke luar batas desanya, sementara orang Penengahan bertebaran membuka lahan hutan di sepanjang pesisir Krui.
} 
untuk jangka panjang. Tidak diperlukan perawatan khusus sampai ia produktif. Bahkan petani membiarkan tanaman-tanaman repong yang dibudidayakannya semasa mengurus kebun untuk hidup berdampingan dengan segala macam tumbuhan kayu dan tumbuhan semak yang tumbuh liar. Dengan tampilan yang demikian, maka repong damar memasuki kategori lahan yang lazim dikenal dengan sebutan wanatani (agroforest), dan bisa digolongkan sebagai sebuah complex agroforestry. Ada sekitar 10 jenis tanaman produktif yang biasa ditanam petani di dalam repong damar (lihat Tabel 5) dan sekitar 78 jenis tumbuhan yang diidentifikasi sering dimanfaatkan oleh penduduk untuk berbagai keperluan, seperti kayu bangunan rumah, perkakas, bahan obat, kayu api, dan lain-lain (lihat Amir Nadapdap 1995; Zulkifli Lubis 1996).

Jumlah dan sebaran jenis-jenis tanaman produktif pada fase repong sangat variatif antara satu bidang dengan bidang lain atau antara satu atar dengan atar lain. Sebagai contoh, laporan Iwan Tjitradjaja (1994:54) menyebutkan bahwa dalam satu sampel plot seluas $3500 \mathrm{~m}^{2}$ pada sebidang repong damar di desa Way Sindi terdapat 41 pohon damar, 5 duku, 4 durian, 5 jengkol, 4 cempedak, 1 petai, 1 melinjo, 102 kayu sungkai, 10 kayu kalawai, dan banyak lagi tumbuhan yang tidak teridentifikasi. Sebidang kebun damar tua yang diamati oleh G. Michon \& Hubert de Foresta (1994:10) memperlihatkan bahwa $65 \%$ dari tegakan yang ada didominasi oleh pohon damar, 20-25\% pohon buah-buahan, dan 10-15\% lainya terdiri dari pepohonan liar dan tumbuhan semak.

Proses pengelolaan lahan hutan dengan tiga fase produktif seperti diuraikan di atas dapat diringkas dalam skema berikut.

\section{Repong Damar dalam Perekonomian Rumah Tangga}

Repong damar baru benar-benar produktif setelah berusia di atas 20 tahun. Ketika itu pohon damar sudah bisa ditakik untuk mendapatkan resin. Pohon buahbuahan, petai, jengkol, dan jenis-jenis tanaman lain sudah menghasilkan sebelum berumur 20 tahun, sehingga petani pemiliknya secara berkala (terutama ketika musim buah) sudah mulai mengunjungi lahan repongnya kembali setelah ditinggal 5-10 tahun. Dengan mulai berproduksinya pohon damar yang ada di sana, maka frekwensi kunjungan petani ke repong damar semakin sering dan berlangsung terus-menerus sepanjang damar masih bisa menghasilkan. Itulah awal dimana lahan repong damar masuk menjadi bagian inti dari perekonomian rumah tangga petani Krui.

Bersamaan dengan itu repong damar juga memasuki suatu jalinan pranata yang kompleks dalam sistem budaya orang Krui, berkenaan dengan pranata pengelolaan, penguasaan, pemilikan dan aturan pengalihan hak. Semua itu bermuara pada pengaturan bagaimana repong damar bisa memberikan kontribusi yang signifikan dalam sistem perekonomian mereka. Berikut ini akan diuraikan ringkas berbagai jenis pengaturan itu. Seseorang bisa mendapatkan hak kepemilikan atas bidang repong damar melalui tiga cara, yaitu (1) membuat sendiri, (2) menerima warisan, dan (3) membeli. Sedangkan hak untuk menguasai dan mengusahakan repong damar dimungkinkan melalui enam cara lagi yakni melalui (1) warisan, (2) gadai/sanggal, (3) serahkelola/ngandan, (4) bagi-hasil/ paroan, (5) upahan, dan (6) menyewa/pak.

Selain itu, dilihat dari jenis pekerjaan yang bisa memberikan penghasilan dari repong damar, seseorang bisa mendapatkan hasil dari repong damar dengan cara (a) ikut memanen getah damar (ngunduh), (b) bekerja upahan membuat pepat di batang damar (mepat), (c) mengumpulkan bijih damar yang jatuh berserakan di bawah batang damar (ngelahang). Pekerjaan yang disebut terakhir biasanya dilakukan oleh ibu-ibu rumah tangga sambil mereka mengumpulkan kayu api dan meramu sayuran di dalam repong damar (tandang midang). Ketika resin damar dibawa petani ke pasar (pedagang pengum-pul atau cecingkau di tingkat desa), perolehan tidak langsung dari repong damar juga didapatkan penduduk melalui pekerjaan-pekerjan seperti (a) ngambica, yakni menjadi buruh angkut damar, dan (b) mileh, yaitu bekerja menyortir damar di gudang.

Dengan berbagai cara pengaturan dan jenis-jenis pekerjaan tersebut hampir semua rumah tangga, atau anggota-anggota sebuah rumah tangga, baik yang memiliki bidang repong damar maupun yang tidak memiliki sama sekali, bisa memperoleh peluang untuk menadapatkan hasil dari repong damar. Jika sebuah keluarga tidak memiliki repong damar dari warisan, ia dapat membuat sendiri repong damar dengan cara pergi membuka hutan. Selain itu dia juga bisa mengusahakan repong damar milik orang lain dengan cara ngandan (serah-kelola) atau mendapatkan kepercayaan dari pemilik repong tsb; tapi bisa juga dengan cara menerima gadaian repong damar orang lain; mengelola repong orang lain dengan cara bagi hasil (paroan); atau upahan ngunduh; atau menyewa repong orang lain. Bagi kaum perempuan di dalam sebuah rumah tangga bisa juga pergi ngelahang di lahan repong orang lain; atau menjadi buruh angkut dan sortir; atau melakukan kombinasi dari berbagai kegiatan tersebut; dan lain sebagainya. Dengan demikian, keberadaan repong damar sangat signifikan dalam menopang gerak perekonomian sebuah rumah tangga petani Krui.

Seperti telah disebutkan di atas, membangun repong damar adalah sebuah bentuk investasi jangka panjang. Seseorang yang membuka hutan menjadi ladang, kebun hingga repong damar, hampir tidak bisa menikmati hasil repong damarnya selagi dia masih hidup, kecuali kegiatan membangun repong damar itu dilakukannya ketika masih berusia muda. Ketika lahan 
repong damar yang ia bangun mulai produktif, maka pengelolaannya biasanya sudah mulai berpindah kepada generasi kedua (anak-anaknya). Karena itu, lahan tersebut sudah menjadi harta milik keluarga atau rumah tangganya. Adat orang Krui menentukan bahwa harta bekas tangan orang tua harus diwariskan kepada anak lelaki sulung (sai tuha bakas) dalam keluarga itu (generasi kedua); dan selanjutnya harta itu akan diwariskan pula kepada anak lelaki sulung pada gene- rasi ketiga; demikian seterusnya. Harta pusaka yang demikian tidak bisa dimiliki melainkan hanya dikuasai, dan pengalihan hak milik kepada orang lain di luar anggota keluarga harus seizin anggota-anggota keluarga luas. Dengan demikian, sebidang lahan yang tadinya berupa unit produktif yang menjadi hak eksklusif sebuah rumah tangga, secara perlahan berubah menjadi harta "milik bersama" (commonproperty right) keluarga luas.

Skema 1. Proses Pengelolaan Lahan Hutan

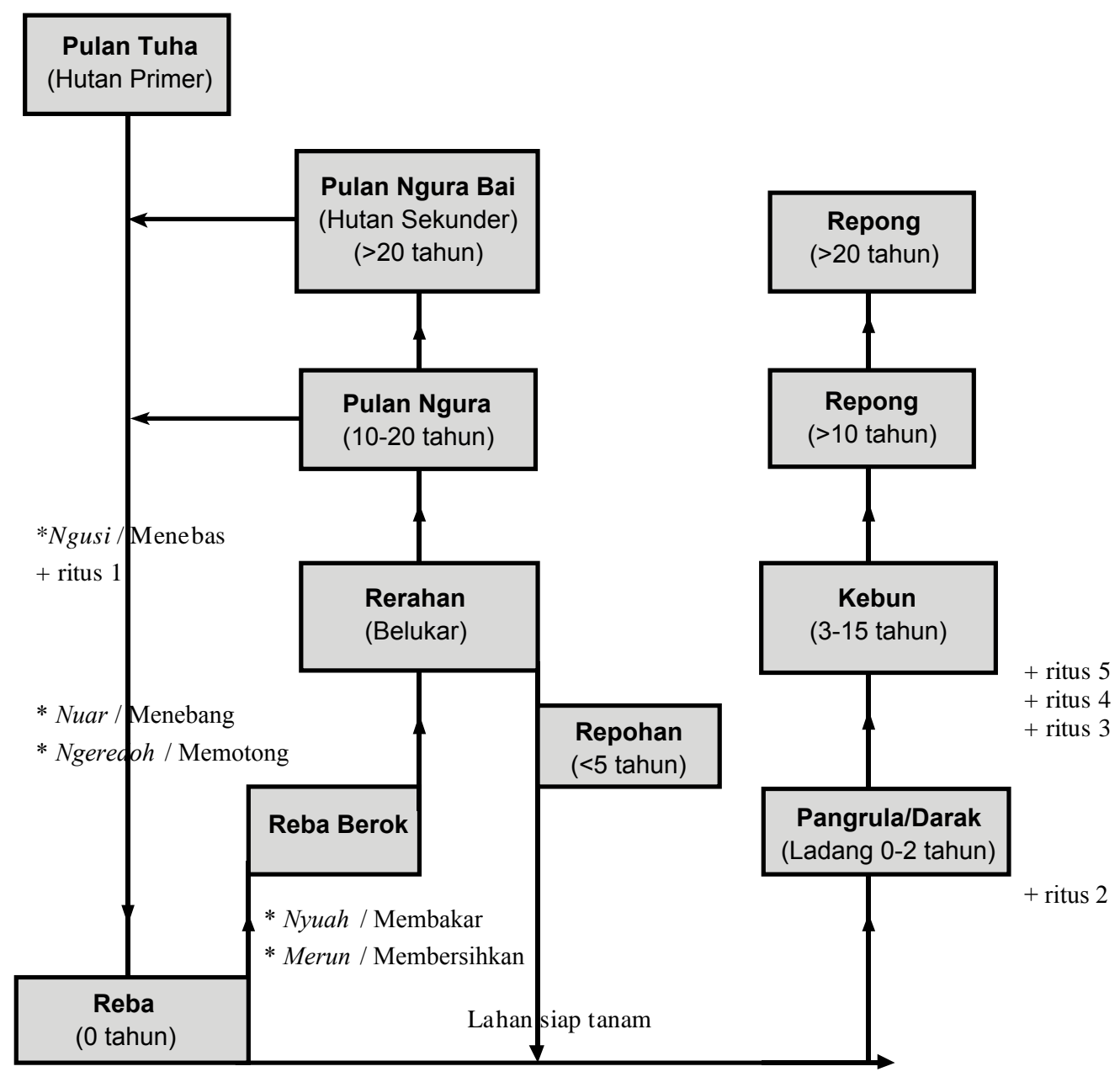

\section{Keterangan:}

Lahan hutan yang lazim dibuka adalah hutan primer atau hutan sekunder. Lahan yang ditebas, ditebang hingga siap bakar disebut reba. Lahan yang siap bakar dan siap tanam disebut pangrula atau darak, yang secara perlahan akan berevolusi menjadi kebun dan repong. Adakalanya reba terpaksa ditinggal karena tak sempat dibakar karena keburu hujan atau alasan lain, sehingga lahan itu kembali menjadi belukar (reba berok atau rerahan) dan hutan (pulan ngura, pulan ngurai bai). Jika lahan rerahan yang baru ditinggal digarap kembali, lahan itu disebut repohan dan selanjutnya menjadi darak, kebun hingga repong. Meskipun struktur hutan pulan ngura bai sudah menyamai pulan tuha, orang Krui tetap menggolongkannya sebagai hutan sekunder, karena sudah pernah ditebas oleh manusia.

Ritus 1 adalah ritus ngebabalih (intinya membina hubungan damai dengan makhluk halus penguasa hutan); ritus 2,3 ialah ritus tetumbai (pada saat menanam); ritus 4 adalah ritus ngejalang (pada saat menjelang panen); ritus 5 adalah ritus ngumbai (pada saat pasca panen). 
Akumulasi penguasaan harta pusaka pada anak lelaki sulung sesuai adat pewarisan Krui, menyebabkan ekonomi rumah tangga para sai tuha bakas ini umumnya relatif lebih mapan dan kuat dibandingkan dengan adik-adik mereka. Posisi yang elitis sesuai adat itu mendorong adik-adik mereka untuk membangun ekonomi rumah tangganya dengan daya kekuatan mereka sendiri, sehingga gerak ekspansi pembukaan lahan baru biasanya dimotori oleh kalangan ini. Alternatif lain bagi mereka adalah memasuki dunia dagang, yaitu menjadi pedagang pengumpul di tingkat desa. Hal yang cukup menarik, akumulasi keuntungan dagang yang mereka peroleh biasanya diinvestasikan untuk membeli atau menerima gadaian lahan repong damar. Dalam konteks yang demikian, peranan repong damar bukan lagi sekedar sebuah unit produktif yang menyangga kebutuhan ekonomi rumah tangga, melainkan juga menjadi atribut yang mengukuhkan status sosial keluarga itu di tengah komunitasnya.

\section{PENGARUH-PENGARUH YANG MENDASARI PENGAMBILAN KEPUTUSAN}

Dari analisis terhadap data-data lapangan, baik melalui wawancara secara umum dan analisis terhadap kasuskasus pengambilan keputusan di tingkat rumah tangga, secara garis besar ditemukan paling sedikit ada empat jenis pengaruh yang mendasari keputusan petani Krui dalam pengelolaan lahan hutan. Keempat jenis pengaruh itu adalah (1) pengaruh ekonomis, (2) pengaruh ekologis, (3) pengaruh sosial, dan (4) pengaruh kultural.

Pengaruh ekonomis mencakup rangsangan yang hadir dalam wujud variabel-variabel ekonomi, seperti fluktuasi harga, akses pasar, modal (material, tenaga kerja dan waktu), dan kebutuhan ekonomi rumah tangga. Pengaruh ekologis meliputi kualitas tanah, topografi lahan, dan perilaku tanaman. Pengaruh sosial meliputi status sosial dan hubungan-hubungan sosial. Pengaruh kultural mencakup pengetahuan, kepercayaan dan nilai-nilai budaya yang terkait dalam pengelolaan lahan hutan.

\section{Pengaruh Ekonomis}

Alasan pertama yang mendorong seseorang memutuskan untuk pergi membuka hutan tidak lain adalah pengaruh ekonomi. Di atas telah disebutkan berbagai keuntungan ekonomis yang akan diperoleh petani dalam seluruh rangkaian aktivitas pengelolaan lahan hutan. Jenis pendapatan yang diperoleh dari pengelolaan lahan hutan sangat beragam misalnya dalam bentuk hasil pangan, uang tuanai dalam jangka pendek maupun jangka panjang, pendapatan rutin dari getah damar, penadapatan berkala dari hasil buah-buahan, dan juga pemanfaatan hasil hutan ikutan yang bisa menghasilkan uang tunai maupun dalam bentuk natura. Kesinambungan hasil yang bisa dimanfaatkan sepanjang tahap-tahap pengelolaan lahan hutan itu menjadi pengaruh bagi petani Krui untuk tetap mempertahankan model pengelolaan repong damar.

Pengambilan keputusan dalam memilih jenis tanaman yang akan dibudidayakan di lahan darak, kebun dan repong didasari oleh pengaruh ekonomi. Sebagian di antaranya hanya sebatas kebutuhan subsistensi, khususunya pada fase ladang; tapi sebagian lainnya didasari oleh adanya permintaan pasar. Komersialisasi beberapa jenis tanaman palawija jelas dirangsang oleh akses ke pasar yang semakin mudah. Dalam kasus dimana lokasi lahan petani jauh dari pasar, atau transportasi masih menjadi kendala, petani menanam tanaman palawija dengan orientasi yang sepenuhnya subsisten. Tapi dalam kasus dimana akses ke pasar cukup mudah, petani mulai menggunakan faktor komersial sebagai dasar pengambilan keutusan. Petani di desa Malaya yang baru lepas dari isolasi perhubungan darat sejak 10 tahun lalu menggunakan istilah "naik timbangan" untuk menggambarkan adanya beberapa produk pertanian yang sudah bernilai komersial bagi mereka.

Tabel di bawah ini menyajikan gambaran variasi jenis dan jumlah tanaman tua yang dibudidayakan oleh tujuh keluarga petani asal Penengahan di tiga atar di daerah Pugung (Kec. Pesisir Utara), yaitu di atar Rata Agung, Way Gedau dan Way Simpanng Lunik.

Tapi harus segera diingat bahwa faktor permintaan pasar itu bukan hal yang baru bagi petani Krui. Dalam menentukan jenis tanaman yang akan dibudidayakan pada fase kebun, mereka sepenuhnya menggunakan pertimbangan akses pasar sebagai hal pokok. Fluktuasi harga yang tajam mempengaruhi petani dalam memutuskan jenis tanaman yang akan dibudidayakan. Kasus melonjaknya harga cengkeh pada tahun 1970-an mendorong petani untuk berlomba-lomba menanam cengkeh, dan ketika harga cengkeh merosot tajam mereka segera pula mengeliminasi cengkeh dari pilihannya. ${ }^{13}$

Hal yang agak berbeda terjadi dalam pengambilan keputusan untuk memilih jenis tanaman tua pada fase repong. Di sini pertimbangan pokok bukanlah harga komoditi tanaman repong pada saat ini, melainkan kontribusi rutin atau berkala yang bisa diberikannya

\footnotetext{
13 Pada tahun 1970-an hingga awal 1980-an terjadi lonjakan harga cengkeh hingga mencapai Rp. 15.000/kg, sementara harga damar waktu itu hanya berkisar Rp 75-100/kg. Ketika itulah banyak terjadi kasus petani menebang damar dan berlomba-lomba menanam cengkeh, terutama di desa Malaya.
} 
Tabel 6. Variasi Jenis dan Jumlah Tanaman Tua oleh 7 Keluarga di Pugung

\begin{tabular}{|c|c|c|c|c|c|c|c|}
\hline \multirow{2}{*}{$\begin{array}{l}\text { Jenis tanaman } \\
\text { (batang) }\end{array}$} & \multicolumn{3}{|c|}{ Rata Agung } & \multicolumn{3}{|c|}{ Way Gedau } & \multirow{2}{*}{$\begin{array}{l}\text { Way S. Lunik } \\
\text { K7 }\end{array}$} \\
\hline & $\mathrm{K} 1$ & $\mathrm{~K} 2$ & K3 & K4 & K5 & K6 & \\
\hline Damar & 200 & 200 & 100 & 100 & 200 & 1000 & 100 \\
\hline Duku & 500 & 100 & 300 & 50 & $<50$ & 100 & 30 \\
\hline Durian & 200 & 100 & $<50$ & 10 & - & $<100$ & 20 \\
\hline Jengkol & - & - & - & - & - & - & - \\
\hline Kayu manis & 100 & 10 & - & - & - & $>500$ & 100 \\
\hline Petai & $>100$ & $>50$ & 30 & 10 & 50 & - & 30 \\
\hline Melinjo & 1 & 4 & - & - & - & - & 5 \\
\hline Luas lahan (ha) & 1,0 & 2,5 & 1,5 & 1,5 & 2,0 & 2,5 & 1,0 \\
\hline Tahun buka & '86 & '84 & '85 & ‘92 & '89 & ‘91 & '89 \\
\hline Transportasi & \multirow{2}{*}{\multicolumn{3}{|c|}{$\begin{array}{l}\text { ojek, mobil } \\
0-2 \mathrm{~km} /<1 \text { jam }\end{array}$}} & \multirow{2}{*}{\multicolumn{3}{|c|}{$\begin{array}{l}\text { ojek, jalan kaki } \\
5-6 \text { km/3-4 jam }\end{array}$}} & jalan kaki \\
\hline Jarak dari aspal & & & & & & & $4-5 \mathrm{~km} / 2-3 \mathrm{jam}$ \\
\hline
\end{tabular}

Sumber: Wawancara

dalam jangka panjang. Naik atau tidak harga jual getah damar misalnya tidak menjadi alasan penting bagi mereka untuk menunda penanaman damar. Dalam kasus maraknya penanaman cengkeh pada tahun 1970an memang banyak petani yang menunda penanaman damar. Tapi hal itu terutama bukan disebabkan oleh faktor harga, melainkan didorong oleh karakteristik botanis tanaman cengkeh yang tidak menghendaki adanya tegakan rimbun lain yang menghalangi penyinaran. Argumentasi ini diperkuat oleh fakta bahwa mereka juga tidak menanam tanaman tua lainnya seperti duku, durian maupun petai dan jengkol bersamaan dengan tanaman cengkeh.

\section{Pengaruh Ekologis}

Hal kedua yang mendasari keputuan petani Krui dalam mengelola lahan hutan adalah pengaruh ekologis. Pengetahuan dan pemahaman mereka mengenai karakteristik ekologis daerah Krui sangat menentukan dalam membuat keputusan untuk mengelola lahan hutan dengan sistem repong. Penilaian terhadap keadaan tanah dan iklim menjadi acuan bagi petani dalam menentukan jenis tanaman apa yang akan dibudidayakan. Jika keadaan tanah dan iklim di suatu lokasi lahan dinilai tidak sesuai untuk jenis tanaman tertentu mereka akan mengeliminasi jenis tanaman tersebut dari alternatif jenis tanaman yang akan dipilih.

Beberapa kasus pengambilan keoputusan yang dikaji menunjukkan bahwa petani asal Penengahan yang membuka lahan di daerah Liwa mengeliminasi tanaman lada dan damar karena mereka berpendapat bahwa kondisi tanah dan iklim di daerah itu tidak sesuai untuk tanaman tersebut. Tapi harus dipahami bahwa selalu ada variasi individual dalam pengambilan keputusan meskipun pengetahuan mereka mengenai karakteristik ekologis relatif sama.

Pengetahuan petani Penengahan dan Malaya mengenai karakteristik botanis tanaman kebun khususnya kopi dan lada, membawa implikasi yang berbeda bagi keputusan mereka dalam memilih jenis tanaman kebun. Pengetahuan mereka mengenai aspek pemeliharaan, masa siap panen, dan produktivitas tanaman lada dan kopi pada prinsipnya sama, tapi tidak sekaligus menjadi patokan bagi mereka untuk membuat pilihan yang sama. Petani Penengahan lebih mengutamakan tanaman kopi daripada lada, sementara petani Malaya lebih mengutamakan lada.

Faktor ekologis dan karakteristik botanis tanaman selalu dikaitkan petani dengan pertimbanganpertimbangan ekonomi. Dalam kaitan ini terdapat variasi antara petani Penengahan dan Malaya khususnya ketika mereka harus menentukan prioritas pilihan antara tanaman lada dan kopi. Petani Penengahan memandang sangat tidak ekonomis untuk mengutamakan tanaman lada, karena akan membuang banyak waktu menunggu hasil panen. Sebaliknya petani Malaya berpendapat bahwa menginvestasikan tenaga, waktu dan modal yang cukup besar untuk mengurus kopi tidak memberikan keuntungan yang jauh lebih besar, karena harga jual kopi dan lada selalu berimbang; sedangkan hasil per batang tanaman lada lebih banyak daripada kopi dan usia produktif tanaman lada lebih panjang daripada kopi. 
Tabel 7. Tipologi Tanah menurut konsepsi petani Krui

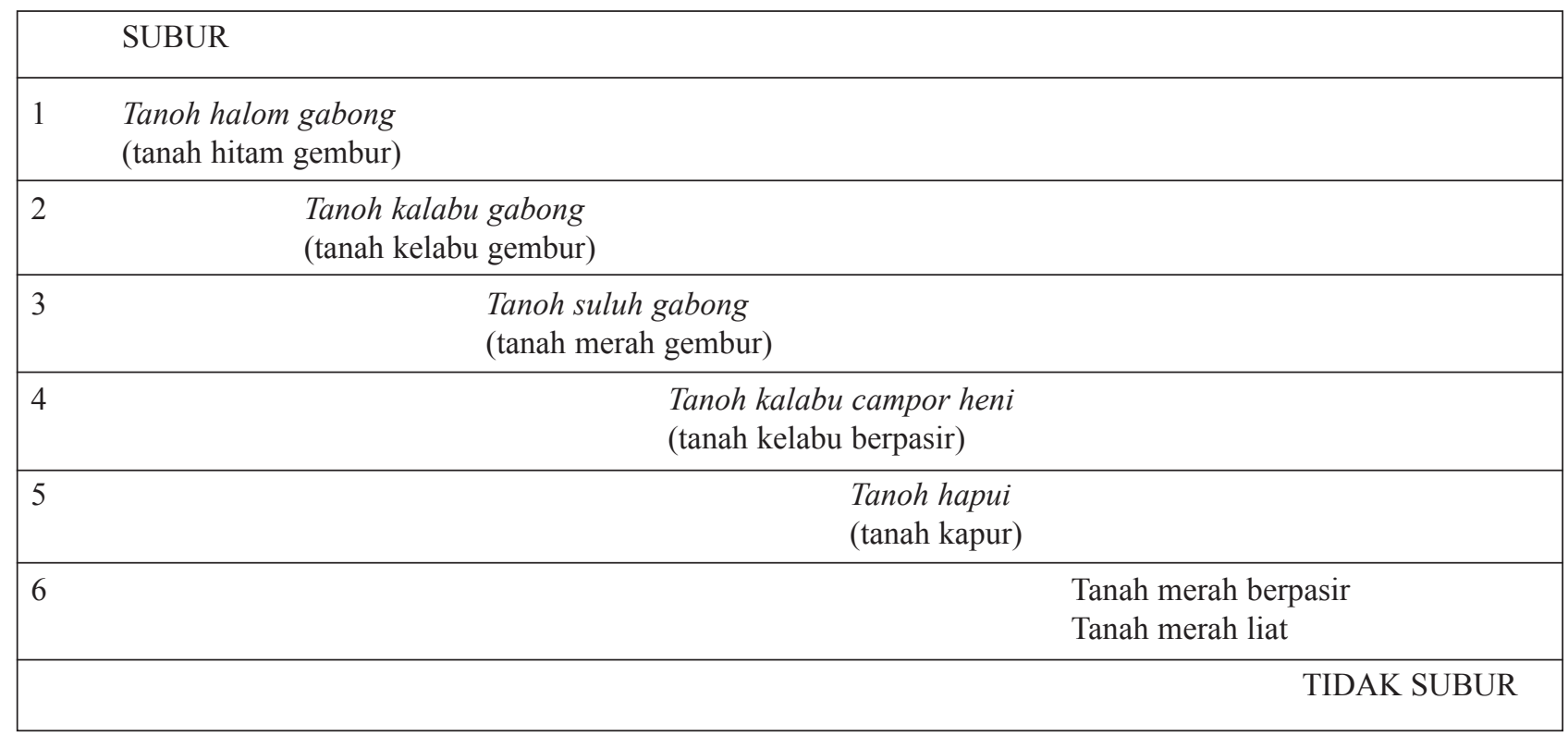

Sumber: Wawancara

Pengetahuan petani mengenai sifat-sifat tanaman juga sangat menentukan dalam proses pengambilan keputusan memilih jenis tanaman. Sebagai contoh, para informan mengatakan bahwa tanaman padi dan palawija yang ditanaman pada fase ladang tidak bisa ditanam secara berbaur. Dalam praktiknya petani biasanya membagi lahan ladangnya atas dua bagian, sebagian untuk ditanami padi dan sebagian lagi untuk palawija. Demikian pula pada fase kebun, para petani berpendapat bahwa jenis tanaman yang bisa ditanam bersamaan hanya sedikit, karena karakteristik fase kebun adalah kecenderungan monokultur. Seperti telah disebutkan, ada tiga jenis tanaman kebun yang populer bagi orang Krui yaitu kopi, lada dan cengkeh. Kopi dan lada bisa dikombinasikan tapi salah satu harus ditanam dalam jumlah lebih sedikit; sedangkan cengkeh biasanya ditanggapi sebagai tanaman yang kurang toleran dengan kehadiran tanaman-tanaman lain di lahan yang sama.

Berbeda dengan fase kebun, faktor toleransi tanaman tidak menjadi pertimbangan yang penting bagi petani dalam menentukan pilihan kombinasi jenis tanaman untuk ditanam pada fase repong damar. Hal itu berkaitan dengan pemahaman mereka bahwa repong adalah kebun campuran yang bisa ditumbuhi beranekaragam jenis tanaman sekaligus.

Tabel 8. Rentang Kesuburan Tanah Menurut Ciri Vegetasi

\section{SUBUR}

Ditumbuhi pohon-pohon besar, tegakan jarang, batang lunak, tidak mudah tumpul (genawah)

Tanah yang ditumbuhi banyak pohon beringin (bunuk)

Banyak tumbuhan liana (bait) berukuran besar

Banyak tumbuhan bebadar, gayau dan jutang

Banyak tumbuhan rotan (hui sesuh dan hui meranau)

Banyak tumbuh rotan hijau dan rotan gelang

Banyak tumbuh paku asam

Tumbuh-tumbuhan kayu kerdil, tegakan rapat, penampang keras, banyak kayu bernas dan kayu berpasir.

TIDAK SUBUR 


\section{Pengaruh Sosial}

Pengaruh ketiga yang mendasari keputusan petani Krui dalam mengelola lahan hutan dengan sistem repong damar adalah pengaruh sosial. Membuka hutan merupakan inisiatif dan keputusan seorang individu. Tapi mengapa dan untuk apa ia pergi membuka hutan tidak terlepas dari pengaruh lingkungan sosial dimana ia hidup. Kemudian, beban kerja yang harus dipikul dalam seluruh tahapan pembukaan lahan hutan biasanya akan menjadi lebih ringan karena adanya bantuan dari orang lain di lingkungan sosialnya, baik anggota keluarganya sendiri, kerabat dan tetangga satu atar. Orang Krui mengenal tradisi pengerahan tenaga kerja yang disebut ketulungan dan bebelinan. Yang pertama identik dengan gotong royong berdasarkan sukarela dan tanpa imbalan; sedangkan yang kedua sama dengan arisan tenaga. Tradisi demikian masih berlaku dalam pembukaan lahan hutan di daerah Krui hingga sekarang. Dengan demikian seseorang yang pergi membuka hutan tidak akan merasa sendirian karena orang-orang yang ada di sana akan membentuk sebuah komunitas non-permanen yang anggotanya biasanya terdiri dari para petani yang berada di satu atar.

Selain itu faktor dukungan orang tua sangat besar peranannya dalam pengambilan keputusan untuk pergi membuka hutan. Seseorang yang pergi membuka hutan ketika masih bujangan atau baru berumah tangga biasanya mendapat bimbingan dari orang tuanya. Proses duplikasi sistem pengelolaan yang bermula dari ladang, kebun hingga repong damar biasanya berlangsung dengan kehadiran aktor dari dua generasi sekaligus, yaitu orang tua (generasi pertama) dan anak lakilaki (generasi kedua). Ketika aktor generasi kedua ini sudah berangkat tua, ia akan membimbing anakanaknya lagi (generasi ketiga) membuka hutan seperti yang ia terima dari orang tuanya. Demikian seterusnya ke generasi-generasi berikutnya. Keterlibatan orang tua di dalam proses tersebut akan menentukan terhadap bentuk pengelolan lahan.

Hal lain yang berkaitan dengan pengaruh sosial untuk mengelola lahan hutan dengan sistem repong damar adalah terbukanya peluang bagi seseorang atau sebuah keluarga untuk naik kelas sosial di lingkunngan komunitas desanya. Aturan adat pewarisan orang Krui menentukan bahwa harta pusaka akan diwariskan kepada anak lelaki sulung dalam satu keluarga. Hal ini mengakibatkan anak lelaki yang lahir kemudian tidak akan mendapatkan porsi yang memadai dari harta warisan peninggalan orang tuanya. Dari penelusuran data kepemilikan lahan repong di Penengahan dan Malaya terkuak fakta bahwa sekitar dua-pertiga bidang repong damar yang berusia tua di kedua desa berada di bawah penguasaan anak lelaki sulung. Menumpuknya sumberdaya di tangan seseorang sudah tentu membawa implikasi pada munculnya sikap elitis yang akan menempatkan seseorang tersebut dalam posisi yang lebih tinggi pada jenjang struktur sosial. Pada gilirannya, pemilikan repong damar menjadi simbol status sosial. Keadaan ini menjadi pengaruh bagi orang yang belum punya repong damar untuk memutuskan pergi membuka hutan. Sejumlah kasus menunjukkan bahwa hasil uang tunai yang mereka peroleh pada fase kebun banyak dimanfaatkan oleh para anak singura (anakanak lelaki yang bukan anak sulung) itu untuk menerima gadaian atau membeli repong damar, sehingga dengan penguasaan terhadap repong damar tersebut bisa menyetarakan kedudukan mereka dengan orangorang yang mendapatkan repong damar dari warisan.

\section{Pengaruh Kultural}

Petani Krui menempatkan fase-fase pengelolaan lahan hutan mulai dari ladang, kebun, hingga repong damar pada tataran yang berbeda. Ladang ditanggapi sebagai fase yang berfungsi untuk memenuhi kebutuhan subsistensi. Pemilihan jenis tanaman pada fase ladang seperti telah dikemukakan di atas didasarkan pada kepentingan subsistensi, bukan komersial. Ladang diposisikan sebagai pendukung bagi fase kebun. Fase kebun ditanggapi sebagai fase batin kejutan/kaya kejutan. Artinya, tanaman yang dibudidayakan di kebun bisa memberikan efek kejutan kepada pemiliknya jika ia sampai pada tahap pencapaian yang disebut merawan. Dengan hasil kebun seseorang bisa mewujudkan banyak hal yang bersifat monumental dalam kehidupannya, misalnya membangun rumah, menerima gadaian atau membeli sawah dan repong damar, modal untuk berdagang, naik haji, membiayai pendidikan anak, dan lain sebagainya.

Petani Krui memilih untuk mengakhiri fase ladang dan memulai fase kebun karena mengharapkan perolehan hasil yang lebih banyak dari lahan yang sama. Dari semua informan yang diwawancarai tak seorang pun yang memilih untuk berhenti mengelola lahan sampai pada fase ladang saja, karena dari awal mereka sudah memasang niat untuk berkebun. Ketika mereka memutuskan untuk meneruskan pengelolaan lahan ke fase repong, pertimbangannya bukan hanya menyangkut faktor keterbatasan alamiah tanaman kebun yang tidak bisa melampaui usia produktif di atas 15 tahun, akan tetapi juga didasari oleh alasan-alasan yang bersifat kultural. Bagi petani Krui, membangun repong damar juga merupakan perwujudan amanah mereka untuk mewariskan sesuatu yang bermanfaat secara kongkrit bagi keturunannya. Mereka ingin menduplikasi apa yang telah diterimanya dari orang tua.

Sejauh fakta yang bisa ditemukan di lapangan, tahapan pengelolaan lahan hutan selalu diakhiri dengan membangun repong damar. Artinya, pengetahuan mereka mengenai tahapan-tahapan pengelolaan hutan dijadikan sebagai acuan dalam tindakan pengelolaan lahan hutan. Tapi hal itu bukanlah suatu keadaan yang 
tanpa gangguan. Paling tidak pengalaman mereka pada tahun 1970-an mencuatkan fakta bahwa sebagian petani justru menghentikan pengelolaan lahan pertaniannya sampai pada fase kebun dan tidak dilanjutkan ke fase repong. Namun ketika tanaman cengkeh mereka musnah diserang hama pada tahun 1980-an sehingga mengguncang ekonomi rumah tangga mereka, maka pengalaman pahit itu mendorong mereka untuk bersikap konservatif hingga sekarang. Era 1990-an ketika penelitian ini dilakukan, petani Krui telah kembali ke format awal model pengelolaan lahan hutan, yaitu mulai dari ladang, kebun, dan berakhir pada fase repong damar.

\section{KESIMPULAN}

Penelitian ini mengungkapkan adanya empat pengaruh yang mendasari keputusan petani dalam pengelolaan lahan hutan yaitu: (a) pengaruh ekonomi, (b) pengaruh ekologis, (C) pengaruh sosial dan (d) pengaruh kultural. Adanya hubungan yang simbiosis antara keempat pengaruh tersebut membawa petani pada pandangan bahwa pengelolaan lahan hutan dengan sistem repong damar adalah pilihan yang paling menguntungkan. Karena setiap fase pengelolaan lahan hutan (darak, kebun dan repong) memberikan kontribusi yang saling mendukung satu sama lain sehingga meminimalkan resiko kegagalan dalam aktivitas pertanian.

Keberlanjutan sistim repong damar sangat ditentukan oleh bertahannya hubungan simbiosis dan terjaganya keseimbangan peran keempat pengaruh diatas dalam proses pengambilan keputusan yang akan dibuat oleh petani. Kasus konversi damar ke cengkeh pada tahun 1970-an merupakan contoh yang memperlihatkan adanya gangguan terhadap keseimbangan peran tersebut, yang sekaligus berpotensi mengancam kelestarian dan keberlanjutan repong damar. Dari ketiga fase pengelolaan lahan hutan tadi, fase kebun menempati kedudukan yang istimewa dalam perspektif ekonomi dan kognisi petani, juga sekaligus sebagai fase yang rawan, rentan dan potensial sebagai titik awal terjadinya perubahan secara ekstrim dalam mode pengelolaan lahan hutan di pesisir Krui. 


\section{DAFTAR KEPUSTAKAAN}

Acheson, James M. 1980. “Agricultural Business Choices in a Mexican Village”. Dalam Peggy F. Barlett (ed) Agricultural Decision Making; Anthropological Contribution to Rural Development. New York: Academic Press. Hal 241-264.

Acheson, James M. dan Bonnie J. McCay. 1987. "Human Ecology of the Commons". Dalam Bonnie J. McCay \& James M. Acheson (ed) The Question of the Commons; The Culture and Ecology of Communal Resources. Tucson: The University of Arizona Press.

Atmaja, Nengah B. 1993. Pengelolaan Hutan Wisata Kera Sangeh oleh Desa Adat Sangeh. dalam Ekonesia 1:1-22.

Barlett, Peggy F. 1980. Agricultural Decision Making, Anthropological Contributions to Rural Development. New York: Academic Press.

Bulmer, R. N. H. 1982. "Traditional Conservation Practices in Papua New Guinea", dalam L. Morauta et al. (eds) Traditional Conservation in Papua New Guinea: Implication for Today. PNG.

Cernea, Michael M (ed). 1988. Mengutamakan Manusia Dalam Pembangunan:Variabel-variabel sosiologi dalam pembangunan Pedesaan. Jakarta: UI-Press.

Colchester, Marcus. 1993. "Forest People and Sustainability" dalam Marcus Colchester \& Larry Lochman (ed) The Struggle for Land and the Fate of the Forests. Penang: World Rainforest Movement. Hal 61- 99.

Dove, Michael R. 1993. "Uncertainty, Humility, and Adaptation in the Tropical Forest: The Agricultural Augury of the Kantu" dalam Ethnology 40 (2): 145-167.

Dove, Michael R. 1993a. A Revisionist View of Tropical Deforestation and Development. Honolulu: East-West Center Environment Series No. 19.

Dove, Michael R. 1994. Transition from native Forest Rubbers to 'Hevea brasiliensis' (Euphorbiaceae) among Tribal Smallholders in Borneo. Honolulu: East-West Center Reprints Environment Series No. 21.

Dougherty, J.W.D. 1985. Directions in Cognitive Anthropology. Urbana: University of Illinois Press.

Dupain, Dominique. 1994. Une Region Traditionallement agroforestiere en mutation: le Pesisir. ORSTOMBIOTROP. Bogor.

Engberg, Lila E. 1988. Rural Household, Resource Allocation and Management: An Ecosystem Perspective.

Eridwiantari, Fenny. 1996. Tata Niaga Damar: Kajian Tentang Hubungan Antar Pelaku Dalam Perdagangan Damar di Krui, Kecamatan Pesisir Tengah, Lampung Barat. Skripsi sarjana antropologi Universitas Indonesia.

Fikarwin. 1996. Reduplikasi dan Koalisi Internal Rumah Tangga: Proses Adaptasi Terhadap Perubahan Sistem Produksi dan Pasarisasi di Penengahan Krui, Lampung Barat. Tesis Master. Program Pascasarjana Antropologi Universitas Indonesia.

Gatewood, J.B. 1985. “Actions Speak Louder than Words". dalam J.W.D. Dougherty (eds) Direction in Cognitive Anthropology. Urbana: University of Illinois Press.

Gladwin, Christina H. 1980. Theory of Real-life Choice: Application to Agricultural Decision”. dalam Peggy F. Barlett (eds) Agricultural Decision Making, Anthropological Contributions to Rural Development. New York: Academic Press. Hal. 45-82.

Hadikusuma, H. Hilman Prof. SH. 1990. Masyarakat dan Adat Budaya Lampung. Bandung: CV. Mandar Maju.

Johnson, Allen. 1974. "Ethnoecology and Planting Practices in a Swidden Agricultural Systems". American Ethnologist 1:87-101.

Juhadi. 1995. Repong Damar: Sistem Pengelolaan Sumberdaya Hutan Berkelanjutan di Desa Way sindi, Krui, Lampung Barat. Tesis Master. Program Pascasarjana Antropologi Universitas Indonesia.

Korten, David C. 1987. Community Management: Asian Experience and Perspective. West Harford. Connecticut. Kumarian Press. 
Korten, David C. 1993. Menuju Abad 21: Kelompok Sukarela dan Agenda Global. Jakarta: Sinar Harapan \& Yayasan Obor Indonesia.

LATIN. 1995. Bufferzone Development Project in Bukit Barisan Selatan National Park through Community-based "damar" (Shorea Javanica K\&L) Forest Management. Final report. Latin/Orstrom/Watala.

Michon, Genevieve. 1985. De l'homme de la Foret au Paysan de l'arbre: Agroforesteries Indonessiennes. Tesis.

Mary, Fabienne. 1987. Agroforests et societes Analyse socio-economique de systemes agroforestiere Indonesiens. Montpelliera. Economie et Sociologie Rurales.

Mary, Fabienne \& Genevieve Michon. 1987. When agroforests drive back natural forest: A Socio-economic analysis of rice-agroforest system in Sumatera. Agroforestry System 5:27-55.

Michon G. \& H. de Foresta and N. Widjayanto. 1992. Research on agroforestry systems in Sumatera:some results interesting silviculture. SEAMEO-BIOTROP, Bogor.

Michon, Geneveive \& Hubert de Foresta. 1994. Damar Agroforest in the Pesisir, Sumatera. Paper, tidak diterbitkan.

Nadapdap, Amir Syamsu. 1995. Konsepsi dan Pemanfaatan Ruang dan Sumberdaya: Studi Kasus Masyarakat Petani Damar di Krui, Lampung Barat. Program Penelitian dan Pengembangan Antropologi Ekologi, Program Pascasarjana Universitas Indonesia.

Netting, Robert McC. et al. (eds). 1984. Households: Comparative and Historical Studies of Domestic Group. California: University of California Press.

Orlove, Benjamin. 1980. "Ecological Anthropology”, Annual Review in Anthropology 9:235-273.

Park, Chris C. 1992. Tropical Rainforest. New York: Routledge.

Poffenberger, Mark (eds). 1990. Keepers of the Forest: Land Management Alternatives in Southeast Asia. Manila: Ateneo Manila University Press.

Rao, Y. S. et al. (ed). 1984. Community Forestry: Socio-economic Aspects. FAO-RAPA.

Rathakette, Pagarat et al. 1984. "Taboos and Tradition: their Influence on the Conservation and Exploitation of Tress in Social Forestry Projects in Northern Thailand”. dalam Y. S. Rao et al. (ed).

Raven, Peter H. 1981. Tropical Rain Forests: A Global Responsibility. Dalam “Natural History” Vol. 90 No. 2.

Ryan, John C. 1993. "Melestarikan Keanekaragaman hayati” dalam Lester R. Brown (ed) Jangan Biarkan Bumi Merana. Laporan Worldwatch Institute. Edisi Indonesia. Penerbit Gramedia \& YOI.

Salim, Emil. 1992. "Pembangunan Berkelanjutan: Keperluan Penerapannya di Indonesia", dalam SPES Pembangunan Berkelanjutan, Mencari Format Politik. Yayasan SPES dan Gramedia, Jakarta.

Sayuti, Husin Drs. Hi. 1977. Sejarah Daerah Lampung. P3KD Jakarta.

Soemarwoto, Otto. 1992. Indonesia dalam Kancah Isu Lingkungan Global. Jakarta: PT. Gramedia Pustaka Utama.

Tjitradjaja, Iwan dkk. 1994. Kajian Pengembangan Institusi Masyarakat di dalam dan sekitar Hutan: Kasus Pengelolaan Hutan Damar di Krui Lampung Barat. Laporan Penelitian. Program pasacasarjana Antropologi UI dan Departemen Kehutanan.

Vergara, Napoleon T. 1984. "Expanding Populations and shrinking Resources: The Economic Setting and Development Potential for Social Forestry", dalam Y.S. Rao (ed) Community Forestry: Socio-economic Aspect. FAO/East-West Center.

Zulkifli Lubis. 1996. Repong Damar: Kajian Tentang proses Pengambilan Keputusan Dalam Pengelolan Lahan Hutan di Pesisir Krui Lampung Barat. Tesis S2 Universitas Indonesia. 